\title{
Multi-Level, Recursive Law and Development: Singapore's Legal Role in ASEAN
}

\author{
Andrew HARDING* \\ National University of Singapore, Singapore
}

\begin{abstract}
"Developed" states tend to reflect their own development experience in their dealings with "less developed" states, encouraging replication of their own solutions and processes. This is "recursive" law and development (LAD). This article examines the role of Singapore in LAD processes in the ASEAN region. It finds that Singapore's LAD efforts are recursive and focused on rule-of-law and governance training, including especially anti-corruption methods. These are conducted not via a special agency, but via co-operation that is multilevel, multidimensional, and untrumpeted. LAD can learn lessons from this approach.
\end{abstract}

Keywords: law and development, Singapore, ASEAN, legal technical assistance, rule of law, good governance

\section{INTRODUCTION}

Development trajectories and dynamics are interesting, for many reasons. A particular nation-state's development becomes part of its national story. ${ }^{1}$ Development may occur over a short period of time, as has occurred in Asia during the occurrence of the so-called "East Asian miracle," where economies and societies are transformed with startling rapidity, attaining a kind of Stakhanovite heroism. ${ }^{2}$ As happens also in the West, Asian states tend to see their own experience as somehow indicative, inevitable, and highly replicable elsewhere. ${ }^{3}$ In Southeast Asia, the various states have had somewhat different development trajectories; indeed, looking at those different experiences, one begins to wonder whether there is anything about them that is immediately replicable even within the region, quite apart from beyond it. Yet, as we will see, Singapore's clear and consistent adherence to the rule of

* Andrew Harding is a Professor of Law in the Faculty of Law, National University of Singapore. He specializes in law in Southeast Asia, working on comparative constitutional law and law and development issues. He is a founding editor of the Hart/ Bloomsbury book series, "Constitutional Systems of the World," to which he has also contributed the books on Malaysia and Thailand. His latest book, Law and Society in Malaysia: Pluralism, Religion and Ethnicity (edited with Dian Shah) was published by Routledge in 2017. The author wishes to thanks Jan Michiel Otto for his helpful comments and Bui Thu Hien for her assistance with the original research. Correspondence to Andrew Harding, Faculty of Law, National University of Singapore, 469G Bukit Timah Road, Singapore, 259776. E-mail address: lawajh@nus.edu.sg.

1. Yew (2012).

2. World Bank (1993); Wigdor (2013).

3. This is pursued briefly below. 
law and good governance as global, not just locally resonant, ideals has been influential in the practical application of the rule of law in ASEAN's law and development (LAD). ${ }^{4}$

Southeast Asian states do not just have different development trajectories: they also have different sets of legal endowments - that is to say, legal resources and legal experience. These endowments are reflected (I argue, recursively so in Singapore's case) in how they regard the relationship between LAD and, in particular, how important and relevant they regard the rule of law as it pertains to development. Such experiences also tend towards crystallizing a definition of the rule of law in the national discourse. In Singapore, for example, the rule of law looms very large in national discourse, not just around development, but around more or less everything. ${ }^{5}$ As Singapore's minister for law has stated: "the Rule of Law was for us not only an aspiration and an ideal (important in itself) but also a necessity borne out of exigency." In LAD, as evidenced in legal technical assistance (drafting and advising on law reform) and legal capacity-building (improvement of legal institutions), it is by no means unusual to find that the individual experiences of states are also reflected in the types of external activity they undertake. Thus, it is noted that Japanese LAD often tends to reflect Japanese ideas, while American LAD often reflects American ideas, and so on. ${ }^{7}$ This is what I mean by "recursive" LAD. In the context of ASEAN, I do not imply by this that Singapore seeks to encourage ASEAN states to copy its legal models, important as these have been for Singapore's own development, but rather that it emphasizes the rule of law as a necessary condition for development, based on its own experience. Of course, logically, there is no conclusive reason why experience or theory in one nation would necessarily be beneficial, or even relevant, to another. As Southeast Asia clearly shows, context is everything when it comes to LAD. The conception of rule of law in Singapore is that it is "based on universal principles, which are at the same time sensitively applied to national circumstances." 8

A powerful reason for adopting "recursive LAD" lies of course in the interests, not just the autobiography and ideals, of the "donor" state. Seen in its worst light, LAD has been called a form of neocolonialism; and yet, in most instances these days, there is a request from the "donee" state for assistance": in Singapore's case, it would of course be hard to accuse of such transgression a city-state of only 720 square kilometres and 5.6 million souls. The role of Singapore in LAD in ASEAN, which is set out in the third section of this article, is probably facilitated by the fact that Singapore has developed with a high degree of success since becoming independent in 1965, and is also a non-threatening presence, but rather a resource, in the ASEAN context. The interests a country has in its own legal models being replicated are that it makes actual legal transactions and development diplomacy much easier; it provides opportunities for that country's law firms and LAD personnel; it spreads soft power; and it encourages the stability of states and their international relations.

4. Deinla (2017).

5. Thio (2012); Lee (2012); Shanmugam (2012).

6. Shanmugam, supra note 5, p. 357. I do not mean to suggest that Singapore's version of rule of law or its complete adherence to rule of law as opposed to rule by law are not controversial issues: for the debates around these questions, see e.g. the articles by Thio, supra note 5; Lee, supra note 5.

7. deLisle (1999); Taylor (2010a); Taylor (2010b); Taylor (2010c); Humphreys (2010).

8. Shanmugam, supra note 5, p. 365.

9. Humphreys, supra note 7, p. 112. 
Recursive LAD is therefore perhaps not so much an overt theory of LAD as an inevitable mode of its actual practice, given the melding of national experience and national interest. However, an important difference that Singapore displays compared to larger players in LAD is that, while it encourages rule-of-law thinking, it does not, at least not overtly or explicitly, attach its own particular legal models to its LAD efforts. The recursive nature of Singapore's LAD is therefore limited, I argue, to its "software" (to use a word that appears often in Singapore discourse around development), by which I mean its rule-of-law discipline, rather than its "hardware," that is Singapore's actual laws and legal institutions. Singapore adheres to a "thin" conception of rule-of-law and communitarian politics. In its work across the ASEAN region, it is thin rule of law that is relevant. ${ }^{10}$

"LAD" usually indicates the efforts of development agencies, national or international, to assist "less developed" states in legislation or the improvement of legal institutions such as judiciary, police, legal professions, and legal education. It also includes scholarly and policy discussion around those issues. However, in recent years, the emphasis has decisively shifted from "external" to "internal" LAD. ${ }^{11}$ In other words, most LAD work is now actually driven by national governments as law reform, not by the international community as legal technical assistance. Admittedly there is fine line to be drawn here, and sometimes the external and the internal overlap, or it is not entirely clear on which side of the line the catalyst lies. But an important part of Singapore's own LAD experience is that its domestic development has been entirely internally driven; it designed its laws to fulfil the project of national development without reference to what was expected internationally, and sometimes in the teeth of international criticism. ${ }^{12}$ The use of "LAD" in this article does not therefore imply just the original and somewhat limited meaning that sees LAD as legal technical assistance delivered by a "donor" or "developed" country or an international agency, such as the Asian Development Bank or the United Nations' Development Programme, to a "donee," "developing," or "less developed" country. Indeed, we will find that, in Singapore's case, LAD is properly regarded as occurring at many different levels and in many different modes, so that the bilateral donor-donee paradigm seems curiously inapt. In terms of the internal-external distinction, Singapore's LAD efforts are simply part of intra-ASEAN co-operation. In some of these levels and modes, LAD as such may even be an unfamiliar concept. At any rate, Singapore may be distinguished from other countries conducting LAD activity in that it does not have any international development agency driving LAD in the way that the American USAID, the Australian AUSAID, and the Japanese JAICA do.

Even a potentially broader-than-usual definition of LAD, as advocated here, may well have a penumbra of uncertainty. For example, an empirical survey of LAD in Singapore ${ }^{13}$ undertaken by the author and Bui Thu Hien in 2016-17 found that Singapore engages in a good deal of training for public officials in ASEAN that might not immediately appear to have a LAD aspect at all, in that it does not have content that LAD practitioners would normally understand as "legal." But, in practice, the spreading of Singapore's rule-of-law and good-governance values in the sphere of public service tends to enhance legal capacity in

10. Thio (2002).

11. McAuslan (2004).

12. A good example of this (Shanmugam, supra note 5, p. 361) is the issue of land acquisition, where Singapore diverged for some years from the commonly understood rule-of-law principle of no acquisition without compensation.

13. Harding \& Bui (2017). 
a broader sense, and provide strong vectors towards legally compliant process and effective integrity systems. These ideas in effect define the rule of law as conceived in Singapore's experience and LAD activity. Such training programmes can therefore legitimately be seen as part of LAD. After all, the "law" side of LAD is supposed to serve the "development" objective, and development has many aspects. ${ }^{14}$

This article therefore discusses the "multilevel" approach to LAD in Singapore, which does not define LAD according to the usual state-centred definition, but operates through many different agencies and initiatives taking place at various governmental and also societal levels. If we perceive LAD in what Newton calls its "post-moment" (i.e. from 2000 onwards $)^{15}$ as being in some sense more pluralistic than LAD in its previous iterations since the early 1960s, then this multilevel and recursive approach should not surprise us. Indeed, one might go so far as to say that this post-moment tracks post-modernism itself in that it allows a plurality of equally valid narratives, rejects colonial or quasi-colonial framing and initializing of the exercise, and involves agencies going beyond the state. To this history of LAD we will return later.

\section{LAD IN SINGAPORE}

Of all the ASEAN states, Singapore is by far the most prosperous, being listed as a highincome state. ${ }^{16}$ It is the only state in ASEAN, apart perhaps from Thailand, that is realistically in a position to devote significant resources to ASEAN regional development and to LAD activity, as opposed to being a recipient thereof. The Singapore government has always seen the rule of law and good governance as part of the "software" that enabled the city-state to improve its GDP per capita by about 100-fold between 1965 and $2011 .{ }^{17}$ Having long since ceased to have the status of a "developing country," 18 Singapore is now therefore clearly potentially a "donor" rather than a "donee" state, if we are to stick to the accepted terminology. It is also a state that has espoused the rule of law and good governance in a deeply embedded fashion. Despite the overt notion of a state based on Confucian or Asian "shared" values, ${ }^{19}$ it is in practice legalism, and legal certainty, that govern society, administration, and private transactions in Singapore, and orientate the city-state to the rule of law as a universal value as well as one that has served Singapore's own development into a prosperous society and a notable common-law jurisdiction. ${ }^{20}$ Demands on and opportunities for Singapore in the LAD field are also emphasized by its position within ASEAN as not simply the most prosperous state, but as a leader in legal expertise, having a deep interest in

14. See UN Sustainable Development Goals (2015), which sets out 17 individual goals and many of these, especially "Peace, Justice and Strong Institutions" (16), have legal relevance.

15. Newton (2008).

16. According to the 2017 Legaltum Prosperity Index, Singapore's economy ranked 17th amongst 149 countries across the globe and 1st in Asia: see Prosperity.com (2017).

17. Shanmugam, supra note 5, p. 358; see also Yew (1998b).

18. As is acknowledged by Yew (1998a) in the very title of one of his books, From Third World to First: The Singapore Story 1965-2000; see also Harding \& Carter (2003); the World Bank has in fact abandoned the distinction between developed and developing countries: see Channel NewsAsia (2016).

19. Singapore Parliament (1991); Tu (1984); Thio, supra note 10.

20. Shanmugam, supra note 5; Thio, supra note 10. 
regional legal integration. ${ }^{21}$ Singapore sees itself as a legal hub for the region, ${ }^{22}$ much like The Hague, which has achieved such status in the context of international law. Examples of this ambition include the establishment of the Singapore International Commercial Court, where judges from various countries sit, ${ }^{23}$ the Singapore International Arbitration Centre, ${ }^{24}$ and the Singapore International Mediation Centre. ${ }^{25}$ Research centres for international law and Asian legal studies have also been established at the National University of Singapore's Faculty of $\mathrm{Law}^{26}$; and some of Singapore's major law firms are now operating with several regional offices. ${ }^{27}$ In Singapore's case, while there is no doubt, as we have seen, that it regards LAD in practice as based squarely on the rule of law, the rule of law is also widely seen in Singapore as the answer to the region's problems in the field of LAD. Advancing the rule of law amongst the ASEAN states is clearly very much in Singapore's interests, and is perceived in Singapore to be decidedly in the interests of the other ASEAN states, and also of course as a binding force for ASEAN itself. ${ }^{28}$

It is therefore the purpose of this article to identify, in the case of Singapore, a LAD policy and to show how such policy recursively reflects Singapore's own experience as one of Asia's "developmental states." 29 Singapore is, of course, limited by its size and population in terms of what it is able to do in this area; but it does nonetheless have considerable resources to bring to bear-professional, legal, and financial—as well as compelling interests to protect or advance. Various institutions in Singapore, public, quasi-public/government-linked, and private, pursue regional development using their own expertise to benefit the region's poorer states. Given the importance of Singapore's government-linked companies and the fact that the government is Singapore's biggest shareholder, we cannot draw the neat distinction between the public and private sectors that might be appropriate elsewhere. Professional bodies, such as the Law Society of Singapore and the Singapore Academy of Law, are also relevant. ${ }^{30}$ Accordingly, we need to look at a range of different institutions in order to discover Singapore's "multi-layered approach" to LAD. This will be done in the third section of this article.

One important lesson that may be drawn from this is that, consonantly with the diversity of contemporary approaches to LAD in the post-moment, ${ }^{31}$ there may be many players, many

21. I do not discuss here regional integration, on which see NUS's Centre for International Law's: see Centre for International Law-National University of Singapore (2018a). However, without doubt, the LAD efforts discussed here are designed, by building capacity and encouraging co-operation, to serve, if not actually accomplish, the objective of regional integration through law. In addition, Singapore's Academy of Law has established the Asian Business Law Institute, whose objectives are to research integration issues for Asia generally, and propose solutions: see Asian Business Law Institute (2016).

22. Menon (2013); see also Ministry of Law Singapore (2017), where it is reported that legal services exported from Singapore more than doubled in value between 2008 and 2016 (SGD760 million).

23. See Singapore International Commercial Court (2018).

24. See Singapore International Arbitration Centre (2018).

25. See Singapore International Mediation Centre (2018).

26. See Centre for International Law—National University of Singapore (2018c); Law School—National University of Singapore (2018a).

27. E.g. Rajah \& Tann operates in ten countries across Asia: see Rajah \& Tann Asia (2018).

28. See further Woon (2015).

29. Tan (2002).

30. See the Law Society of Singapore (2018); Singapore Academy of Law (2018).

31. Newton, supra note 15 , p. 23. 
agendas, and many modes in which LAD operates. In Singapore, LAD is not formalized but smoothly and implicitly crosses public, private, and international bilateral frameworks to deliver effective assistance without tutelage and without coercion: indeed, it is almost as though, in Singapore, LAD dissolves into just what agencies normally do in terms of international outreach. LAD clearly does, nonetheless, actually occur at a meaningful and conscious level, irrespective of whether it represents an explicit policy. In the earlier research project mentioned above, it proved impossible to find a single express statement of international LAD policy by a Singapore government representative in Parliament or in the media. Conversation with a former minister indicated that there would indeed be no such statement to find. ${ }^{32}$ LAD policy in Singapore, therefore, has to be inferred behaviouristically from the LAD activity undertaken. Therefore, in what follows in the third section, we will discover the various ways in which LAD is pursued in practice by various entities in Singapore. This should be of interest to LAD practitioners, officials, and scholars, as it seems to break down the traditional concept of LAD. The term "law" in LAD needs to be read contextually; some aspects of development may well have legal implications and objectives even if not traditionally regarded analytically as part of LAD. Singapore development software includes the idea of good governance as an attitude of mind-a "standard operating procedure." In this respect, the definition of "law," as was explained above, needs to be wider than is conventional in order to capture that which is actually significant developmentally. The Singapore Cooperation Programme (SCP), discussed below, is a good illustration of the artificiality of distinguishing strictly the legal from the non-legal in this context.

Finally in this section, the survey of LAD, Singapore-style, is unlikely to have captured the totality of the activity undertaken. This is precisely because of the prevailing multilevel approach. There will without doubt be many layers that are quite unheralded and known only to the participants and beneficiaries of the relevant activities. We regard this as symptomatic of the "new law and development" 33 in which LAD has become multifaceted and multidirectional, rendering its nature and extent somewhat unobvious to the naked eye. To the extent that such specific instances may have been missed, they will of course simply reinforce, rather than complicate, the argument presented.

\section{SINGAPORE'S UNHERALDED DEVELOPMENT AGENCIES AND THEIR LAW-RELATED PROGRAMMES}

Singapore was of course one of the founding members of ASEAN, which was established in 1967 mainly for the purpose of accelerating economic growth and promoting peace and security between its state members, now ten in number. ${ }^{34}$ However, ASEAN's missions and visions have evolved and expanded over time. From a mere facilitator for creating wealth, peace, and security, ASEAN has developed to see itself as an integrated community that puts people at the centre of its concerns. ${ }^{35}$ During the ASEAN-community-building process, Singapore has, in recent years, become more and more involved in LAD work with ASEAN

32. Conversation with Mr Ho Peng Kee in October 2016.

33. Trubek \& Santos (2006).

34. See ASEAN (2018).

35. ASEAN (2015). 
at the regional level, and (much more significantly) with ASEAN countries at the bilateral level, as we will see. It also sometimes acts as an assisting third party to bilateral activity between an ASEAN and a non-ASEAN state.

Singapore does not, however, as we have seen, have an international development agency. There is, in other words, no standing bureaucracy devoted to international or regional development as such. Nonetheless, there are many agencies in Singapore that direct attention to regional development projects, and many of those are concerned with law, even if they do not specifically call their activity LAD. These include the Ministry of Foreign Affairs, ${ }^{36}$ the Ministry of Law, ${ }^{37}$ the courts, ${ }^{38}$ the Attorney-General's Chambers (AGC), ${ }^{39}$ the Law Society of Singapore, ${ }^{40}$ the Singapore Academy of Law, ${ }^{41}$ the Temasek Foundation, ${ }^{42}$ and the law schools at the National University of Singapore (NUS) ${ }^{43}$ and Singapore Management University (SMU), ${ }^{44}$ as well as the Lee Kuan Yew School of Public Policy at NUS. ${ }^{45}$

Legal capacity-building appears in fact to be the main area of LAD support that Singapore has been providing for ASEAN countries. This support has been delivered in various forms, including the exchange of legal materials, legal drafting assistance, study visits, training workshops, collaborative seminars, and symposia. Most of the assistance rendered by Singapore is directed to Cambodia, Laos, Myanmar, and Vietnam (known in ASEAN-speak as the "CLMV" group of states that, having a lower level of development than the original six Member States, joined ASEAN in the mid-1990s). Amongst these country beneficiaries, Myanmar has been given the most attention and support in terms of capacity-building and judicial reform. Until recently, Myanmar was an infrequent recipient of international assistance, ${ }^{46}$ but Singapore's involvement with Myanmar goes back many years and is intensified in the legal field by the fact the two countries share a common-law heritage. ${ }^{47}$ For example, scholars from NUS have since 2016 authored three books on Myanmar law, drawing to a great extent on common-law similarities between the two countries. ${ }^{48}$ Such scholarship is itself an example of multifaceted LAD, given the paucity of English-language literature on Myanmar law, and the involvement of an academic institution in going some way to improving this situation.

A major effort in this respect has been the SCP, established by the Ministry of Foreign Affairs in 1992. The express mission of this programme is to share Singapore's development experience and provide support to developing countries. The SCP is designed to build capacity in fields that could smooth the developmental path of these states. For the last two decades, the SCP has facilitated and sponsored a number of training events for ASEAN

\footnotetext{
36. See Ministry of Foreign Affairs Singapore (2018a).

37. See Ministry of Law Singapore (2018).

38. See Supreme Court of Singapore (2018b); State Courts-Singapore (2018).

39. See Attorney-General's Chambers (2018).

40. See The Law Society of Singapore, supra note 30.

41. Ibid.

42. See Temasek Foundation (2018).

43. See Law School—National University of Singapore (2018b).

44. See Law School—Singapore Management University (2018).

45. See Lee Kuan Yew School of Public Policy-National University of Singapore (2018).

46. Harding (2014)

47. Zan (2017).

48. Wong (2016); Chan et al. (2017); Harding \& Oo (2017).
} 
countries that have an LAD component. Most of the training is focused on the following topics:

1. Court excellence.

2. Advanced note-taking and project proposal writing.

3. Public policy and administrative reform.

4. Social policy management.

5. Sustainable development and transport planning.

The ASEAN states who are main beneficiaries of this are the CLMV states. ${ }^{49}$

On a bilateral level, the Singapore government has engaged in assisting individual ASEAN countries. The bilateral development projects vary with respect to the different countries concerned but share some common areas, ranging from the exchange of legal materials and study visits, to collaborative seminars, symposia, and provision of scholarships. Bilateral collaboration between Singapore and the assisted countries is often organized formally by signing a Memorandum of Understanding (MoU) at the ministry level. For example, Myanmar and Singapore have signed two official MoUs: the Singapore-Myanmar Integrated Legal Exchange between the Ministry of Law and the Myanmar Supreme Court; and a legal co-operation MoU between the Ministry of Law and the Myanmar AttorneyGeneral's Office. ${ }^{50}$ The MoUs seek to enhance greater understanding of the laws, legal systems, and legal and judicial institutions of Singapore and Myanmar. These objectives were achieved through the exchange of legal materials, study visits, collaborative seminars and symposia, attachments, and scholarships for Myanmar officials. They also expected the parties to the MoUs to develop collaborative education, training, and knowledge transfer to enhance the mutual co-operation between the two countries. ${ }^{51}$ In this process, it is clear that Singapore's knowledge of Myanmar law is as important as Myanmar's knowledge of Singapore law.

Mediation skills are another area of capacity-building that the Singapore government has focused on when training judges in Myanmar. A number of training workshops have been conducted in close collaboration between the Singapore Ministry of Law and the Singapore Mediation Centre. ${ }^{52}$ Beneficiaries of this initiative were 27 Myanmar judges and judicial officers from the Office of the Supreme Court of the Union, the Office of the Judicial Supervision of the Union, the Office of the Chief Justice of the Union, and the District Courts and Township Courts. The objectives of the workshops were to share the experiences of the mediation mechanism for disputes being practised in Singapore courts, and to study the feasibility of these methods for use in Myanmar. ${ }^{53}$

Apart from Myanmar, Vietnam has also received assistance from Singapore in the field of legal and judicial reforms. In particular, Singapore and Vietnam have signed an Agreement on Legal and Judicial Cooperation (March 2008). This co-operation aims for Singapore and

49. Singapore Cooperation Program: see Ministry of Foreign Affairs Singapore (2018c).

50. Straits Times (2014).

51. See Ministry of Law Singapore (2014a).

52. See Singapore Mediation Centre (2018).

53. See the Supreme Court of the Union (The Republic of the Union of Myanmar) (2015). 
Vietnam to collaborate in a wide range of areas, which include the drafting and implementation of laws, development of legal and judicial expertise, development and promotion of domestic and international dispute-resolution mechanisms, including arbitration and mediation, and legal and judicial administration. Co-operation between the two countries can take various forms, including the exchange of legal materials and publications, exchange of visits between relevant personnel (e.g. judges, academics, and legal practitioners), and the promotion of interaction through lectures, conferences, seminars, and symposia. ${ }^{54}$

The Singapore government has also assisted the Laos government to create sustainable economic growth and alleviate poverty. Singapore has played a supporting role through the provision of human-resource training, scholarships, and sharing of experiences. More than 4,000 Lao officials have participated in training courses and study visits since 1993 under the SCP. Areas of training range from English-language training to information technology, civil aviation, and trade promotion. These latter three activities have important legal components. Under the Initiative for ASEAN Integration (IAI) launched by then-Singapore Prime Minister Goh Chok Tong in November 2001, Singapore established the Lao-Singapore Training Centre (LSTC) in Vientiane to increase training opportunities for Lao officials. Since the LSTC was set up in 2001, almost 3,000 Lao officials have been trained there. Even though the initiatives did not specially focus on legal and judicial reforms, they helped to enhance the working capacity of Lao governmental officials, and indirectly to facilitate LAD via their significant domestic roles in Laos. ${ }^{55}$ In this sense, LAD Singapore-style is not distinguished from development assistance in general.

\subsection{Initiatives by Singapore's Courts}

Whereas the SCP is an initiative of the Ministry of Foreign Affairs, LAD more generally is pursued by the collaborative efforts by the judiciary of Singapore that are initiated by the Supreme Court of Singapore.

The main activity of the Supreme Court to assist ASEAN countries is capacity-building for judges. In February 2016, the Supreme Court of Singapore organized training sessions for ASEAN judges on alternative dispute resolution. This was considered a high-profile training programme, since it was a joint project involving all the most important stakeholders in the field, including the International Centre of Excellence for the Practice and Profession of Alternative Dispute Resolution (CIArb), the Supreme Court of Singapore, and the SCP. The programme clearly demonstrates Singapore's efforts in building the knowledge and capacity of judges in all the ASEAN states.

In 2015 and 2016, the Supreme Court of Singapore also sponsored and organized an international training programme called "Excellence in Judicial Education and Research."56 The programme was operated directly by the Singapore Judicial College (SJC), which was established under the auspices of the Supreme Court of Singapore. According to SJC's statistics, there have been more than 450 foreign judges and officials from more than 50 countries, including the other nine ASEAN countries, who have been beneficiaries of the training programmes. ${ }^{57}$ In addition to all the training programmes that brought together

54. See Ministry of Law Singapore (2008).

55. Singapore Technical Cooperation with LAO PDR: see Ministry of Foreign Affairs Singapore (2018b).

56. See Supreme Court of Singapore (2016). 
judges and officials from different countries, SJC and the Supreme Court also organized training classes for specific ASEAN countries. For example, training on the international framework for court excellence was organized specially for local officials in the CLMV countries. Apart from the popular training topic on judicial excellence, the Supreme Court also delivered training for Laos and Myanmar on parliamentary law, rules, and practices, as a part of the Singapore Ministry of Foreign Affairs' IAI, mentioned above. ${ }^{58}$

Apart from sponsoring and conducting training events, the Supreme Court of Singapore has also been active in facilitating the information network between ASEAN judges on transnational child-custody disputes, which is expected to provide information on childrelated issues and judicial training. ${ }^{59}$

Tracing back its reports from the year 2000 to date, the AGC in Singapore have been very actively involved with ASEAN states. However, most of the AGC's activities focus on foreign trade and investment, as opposed to other areas of development. From 2010 onwards, the AGC started to represent Singapore in collaborating with other ASEAN Member States in developing the law relating to regional development, such as the ASEAN Convention on Trafficking in Persons and the Regional Plan of Action. ${ }^{60}$ The AGC has also been actively involved in negotiations relating to the ASEAN Human Rights Declaration. ${ }^{61}$

At the bilateral level, there were several exchanges between the AGC and the offices of the government of Myanmar, such as a visit by delegation members of the Supreme Court of the Union and Union Attorney-General's Office in December 2013. The delegation came to Singapore to learn about the use of information and communications technology in the judicial and legal systems. ${ }^{62}$ Such delegation visits from ASEAN states to various judicial and legal institutions in Singapore are too numerous to be recorded here but they provide valuable insights for the delegations and a basis for further co-operation.

\subsection{Projects of Singapore's Law Schools}

Legal education is one of the biggest areas of LAD support that Singapore has been providing to the ASEAN states.

Singapore's own legal-education system has evolved in such a way as to fully embrace Singapore connectedness with the rest of Asia and the future needs of its legal profession and judiciary. Both NUS and SMU offer core teaching in the legal systems of Asia, which notably include those of the ASEAN countries, as well as those of South- and North-East Asia. $^{63}$

One of the best-known initiatives in this area is the "ASEAN Scholarship"-a scholarship given to law students coming to Singapore from ASEAN countries to study. Singapore's two law schools practising in this scheme $\left(\mathrm{NUS}^{64}\right.$ and $\mathrm{SMU}^{65}$ ) are the two most popular destinations for ASEAN scholars in Singapore.

\footnotetext{
57. See Supreme Court of Singapore (2018a).

58. Supreme Court of Singapore, supra note 56.

59. Vietnam News Agency (2016).

60. See Attorney-General's Chambers (2015).

61. See Attorney-General's Chambers (2013); Attorney-General's Chambers (2012).

62. Ibid.

63. Harding \& de Visser (2017).
} 
With regard to support for legal education more generally, Myanmar has so far been the biggest recipient of Singapore's expertise. In February 2014, as a result of a collaboration between Singapore's Ministry of Law and Myanmar's Ministry of Foreign Affairs, the two law schools in Singapore signed MoUs with two law schools in Myanmar (the Law Departments of Yangon and Mandalay Universities), committing them to co-operation in the development of legal education in Myanmar. The MoUs aimed to promote co-operation in legal education between the four universities, with key areas of co-operation including faculty exchanges, study visits, curriculum planning and design, and pedagogy, as well as the enhancement of legal research and development of resources. ${ }^{66}$ The theory behind these efforts is that legal-education development is an essential underpinning for the longer-term general sustainability of legal and institutional reforms and, by extension, the rule of law.

\subsection{Projects by Specialist Legal Research Centres}

The Centre for International Law (CIL) at NUS has been working on legal issues in ASEAN as one of their main areas of focus. The "ASEAN Integration Through Law: The ASEAN Way in a Comparative Context" (ITL) project has been one of CIL's major research activities during its initial years. The ITL project examines the role of law and the rule of law in Asian legal integration. The project involves over 70 researchers from Asia and around the world. The outcomes of the project support the efforts of ASEAN Member States to achieve the integration of the ASEAN Community. The ITL project has undertaken research on the rule of law in the ASEAN Community, ASEAN and human rights, a Plenary and Course Development Workshop on the ASEAN Economic Community, and other topics. ${ }^{67}$ Since CIL is directly funded by the Ministry of Law, CIL's interest and activities could be seen as equating to the interest of the Singapore government in ASEAN law, development, and integration.

The Yusof Ishak Institute of Southeast Asian Studies (ISEAS) has a general mission to stimulate research and debate within scholarly circles, enhance public awareness of the region, and facilitate the search for viable solutions to the varied problems confronting the region. For ASEAN, the Institute seeks to promote greater understanding of ASEAN and to contribute towards regional co-operation and integration. The centre conducts studies and provides inputs to stakeholders on issues and matters that call for collective ASEAN actions and responses, especially those pertinent to building the ASEAN Community. Apart from working on the ASEAN region, the Institute concentrates on five ASEAN countries individually-Indonesia, Malaysia, Thailand, Vietnam, and Myanmar. For each country, ISEAS navigated their work to fit the nation's contemporary and hotly debated topics, ranging from political dynamics, social change, and cultural trends to political and economic reform, and many more. Activities are also various, including conferences, workshops, seminars, print and e-publications, and timely commentary in the international and local media. ${ }^{68}$ This

64. NUS was unwilling to share statistics relating to this scholarship, such as how many scholarships are awarded and to which countries. This is an example of the unwillingness of Singapore agencies to emphasize the extent LAD activity. The reason appears to be that indicating the numbers might result in questions as to the country-allocation of scholarships: see National University of Singapore (2018).

65. See Singapore Management University (2018).

66. See Ministry of Law Singapore (2014b).

67. See Centre for International Law-National University of Singapore (2018b). 
research highlights areas for policy development and legal change, and also provides insight into areas of change within ASEAN. ${ }^{69}$

\subsection{International Bridges to Justice's Singapore Justice Training Centre}

International Bridges to Justice, a non-governmental organization (NGO), established the Singapore Justice Training Centre (SJTC) as the regional hub of the organization in ASEAN. As one of the first NGOs invited to work in Singapore under the government's International Organisations Development Scheme in 2010, IBJ has developed partnerships with numerous private and public entities, including Singapore's Ministry of Foreign Affairs, academic institutions, and law firms, to lead training programmes and other events. ${ }^{70}$

Criminal justice is the major area of expertise where the SJTC has supported ASEAN countries. The inaugural event for the SJTC delivered a training workshop that gathered participants from Cambodia, Indonesia, Laos, Malaysia, Philippines, Singapore, Thailand, and Vietnam.

Apart from criminal justice training, SJTC has also put forward other initiatives to support ASEAN countries' legal improvement. For example, eLearning was one of the SJTC's other major achievements. It successfully launched 50 eLearning modules in the three years to 30 June 2013. The modules are specific to seven ASEAN countries, namely Cambodia, Indonesia, Laos, Myanmar, the Philippines, Thailand, and Vietnam, as well as India. The topics covered by the modules include the rights of the accused, the rights and obligations of defence attorneys, attorney-client relations, the presumption of innocence, defences, evidence, cross-examination, complaint procedures, pre-trial detention, investigative torture, and preventing torture. ${ }^{71}$

Again, amongst the ASEAN members, Myanmar received special assistance from this organization. There were programmes called "Legal Aid System Training for Myanmar" and the "Regional Legal Aid Forum" that were designed only for Myanmar. While the Legal Aid System Training was attended by high-level government officials and lawyers from the civil society, which marked an unprecedented and progressive step for Myanmar towards legal aid and criminal justice system, the Forum was an unique platform for meaningful engagement between government officials and young lawyers where open discussions and a shared learning experience. ${ }^{72}$

\subsection{Anti-Corruption Efforts by the Singapore Government}

For a decade from 2008 to 2018, Singapore ranked in the top eight countries on Trading Economics' global scale indicating the effectiveness of anti-corruption measures. ${ }^{73}$ It has constantly been praised as a "shining example" of the rooting-out of corruption, using tough approaches and comprehensive strategies. ${ }^{74}$ The strategies that Singapore has employed

68. See Institute of Southeast Asian Studies (2018).

69. Besides these two major centres, a number of joint events have been organized by different centres and public and private sectors in order to discuss ASEAN Community and the UN development goals: see Human Rights Resource Centre (2015).

70. See International Bridges to Justice (2018).

71. Ibid.

72. Ibid.

73. See Trading Economics (2018). 
either directly focus on improving laws for an effective anti-corruption strategy; or concentrate on other law-related measures, including adjudication leading to punishment and deterrence of those who are prone to corruption; effective administration to reduce the opportunities for corruption; and effective enforcement agencies. ${ }^{75}$

Anti-corruption is an area that is of paramount importance in considering Singapore's effort in LAD for ASEAN countries. A corruption-free system at all levels has been seen by Singapore as an indispensable part of a meaningful rule of law. Therefore, Singapore's regional and bilateral efforts in this field fall into the same pattern of LAD as other areas mentioned above, demonstrating Singapore's leadership and interest in enhancing law in the development of other ASEAN countries. However, while Singapore has, as we have seen, been taking initiatives to approach and assist ASEAN countries in other fields, such as legal research and education, strong willingness and direct demand for support have also come from ASEAN countries. For example, Vietnam has proactively reached out for Singapore for legal capacity-building on anti-corruption measures, which is delivered by training courses, seminars, and high-level exchanges. ${ }^{76}$

The effort to help ASEAN countries fight corruption has been implemented by the Corrupt Practices Investigation Bureau (CPIB). This is a government agency with independent capacity for the investigation and prevention of corruption in Singapore. ${ }^{77}$ As with other fields such as legal research and education, through the CPIB, Singapore's assistance to enhance ASEAN's countries' capacity to combat corruption has been focused on three main interrelated areas, including capacity-building, enhancing mutual sharing, and strengthening collaborative efforts on anti-corruption. These objectives have been implemented through a variety of events and activities: study visits, participating in seminars, and organizing international workshops. Singapore also actively establishes good working relationships with its ASEAN member counterparts in the areas of anti-corruption laws and legal enforcement. ${ }^{78}$ At a more official level, CPIB acted on behalf of Singapore's government to sign bilateral MoUs with some ASEAN countries to enhance mutual sharing, capacity-building, and strengthening of collaborative efforts in anti-corruption matters. ${ }^{79}$

Anti-corruption has long been a significant matter in Singapore's national development and rule of law. Its comprehensive approach to combat corruption and the active assistance it has provided to ASEAN countries has mirrored Singapore's own interest. All these efforts, therefore, illustrate Singapore recursive as well as multilevel approach to LAD.

\section{ANALYSIS AND CONCLUSION}

What is "law and development"?

Both "law" and "development" are vague terms. To insert the word "and" hardly makes for any clarity: indeed, it serves only to obfuscate the conceived relationship between the two concepts. In general terms, what people have meant by LAD is the movement started in the

74. Quah (2017), p. 263; International Bar Association (2015).

75. For the Singapore Corrupt Practices Investigation Bureau, see Corrupt Practices Investigation Bureau (2016).

76. Vietnam News Agency (2015).

77. See International Bridges to Justice, supra note 70.

78. Hin (2013).

79. Ibid. 
US in the 1960s and designed to assist the use of law and legal institutions to create structural change in poorer countries. In this sense, "legal technical assistance" and "legal capacitybuilding" do the job better than "LAD." But even these terms obscure the fact that states can in a sense be (and perhaps are better being) responsible for their own LAD; this is McAuslan's "internal" LAD. ${ }^{80}$ LAD is also obscured somewhat by the use of other terms to describe the various activities that may be involved, such as "rule of law promotion," "human rights policy," "private sector development," or "implementation of WTO, ILO or WHO treaties." In Singapore, it is usually referred to simply as "co-operation" or "regional outreach."

LAD's post-moment is perhaps its final moment, not in the sense that it is coming to an end (indeed, judged in monetary terms, it is probably even more of an industry than ever), but rather that it is in the process of dissolving into plural processes, not all of which have normally been regarded as part of LAD. This is an inevitable consequence of the shift from external, donor-driven LAD to internal, government-driven LAD. Singapore radically redesigned parts of its legal apparatus in the 1970s and 1980s in what was essentially an internal LAD exercise. ${ }^{81}$ No legal technical assistance was needed, as Singapore already had adequate human resources, including its own law school, to achieve what it wanted in legal terms. It realized that law was a powerful tool for development, and that the rule of law and good governance were the support system that would ensure the sustainability of its law and its economic development.

In the empirical section of this article, we have seen how, in various ways, Singapore as (now) an external agency has helped ASEAN states to improve their own legal software in areas such as judiciary, anti-corruption measures, legal drafting, legal education, and so on. In many cases, Singapore has responded to specific requests for assistance, as with judicial development in Vietnam and legal education in Myanmar. The object has not been to ensure that these ASEAN states have good legislation or even necessarily legal institutions resembling those of Singapore. Indeed, given that only Myanmar is a common-law jurisdiction in receipt of Singapore's assistance, this would be hard to achieve. No doubt Singapore would not want to be seen as copying the LAD methods and priorities of Western states and international agencies. Rather than forcing its own models onto ASEAN states, it has, as it were, made available the software that its own development experience has shown is essential not just for economic growth, but as a strong basis for the development of society itself.

Singapore's LAD activities have thus been devoted to legal education in the broadest sense, rather than to the betterment of the positive law. While legislation is the traditional main focus of LAD, is it not more beneficial to improve the skills that go into the art and science of legislation and its implementation than to force on a state a particular legislative project or institution that may well fail, especially if the intervention is resented? To use Singapore terminology, it is all about the software, and that in essence captures the Singapore experience of LAD. It is in this sense that legal education cannot really fail, as McAuslan reminds us. ${ }^{82}$ It can also bring together the notions of improving the practical rule of law for the sake of development, and using development to improve the rule of law as a public good

80. Thio, supra note 10 .

81. Carter (2002).

82. Thio, supra note 10, p. 83. 
in itself. LAD is in a sense historically about "them" and "us"; some people see LAD as a continuation of the project of imperial land-grabbing. But it does not have to be. LAD Singapore-style pursues the common project of improving the rule of law and governance across the poorer states of ASEAN. Of course, it is in Singapore's interests that this improvement should occur. But it is also in everybody's interests.

From this brief survey of LAD-related activity in Singapore, a number of things are apparent.

First, these efforts strongly reflect Singapore's own experience of the rule of law and the role of law in development. The Singapore government believes the rule of law to be a universal value, but it is also a matter of pragmatically building the institutions required to entrench it. This occasionally includes diverging from the rule of law in global version where it is perceived to be necessary. ${ }^{83}$

Second, Singapore does not prominently announce or widely proclaim its LAD activity as a model or even as representing the impressive record that it undoubtedly is. We may infer from this that Singapore sees LAD as a mode of entirely voluntary co-operation, not an area for any form of coercion or tutelage. In this sense, it is powerful, but it is soft power. Nonetheless, Singapore clearly believes that an ASEAN based on the rule of law will be highly beneficial to Singapore and to ASEAN. In doing so, it is submitted, it is not wrong, and the ASEAN Charter clearly takes ASEAN in that direction.

Third, Singapore takes a multilevel, multifaceted, multidimensional approach in which its existing institutions, government, judicial, professional, civil society, and academic, have various roles to play. These roles fit together in terms of the kinds of LAD "software" that are needed for rule-of-law entrenchment in ASEAN.

Fourth, Singapore's efforts are mainly, although not exclusively, aimed at the CLMV countries, Myanmar in particular. This reflects a historic close relationship between the two countries as well as the facts that Myanmar's needs are greater than the other states and that Myanmar's opening since 2011 creates a space for those needs to be met.

Fifth, Singapore sees corruption as a major problem, and effective anti-corruption measures as part of building an effective rule of law in ASEAN. This too reflects Singapore's own values and experience of developing the rule of law. This too makes some sense. Corruption is a major problem across ASEAN, and Singapore has shown that a culture of corruption can be denied and reversed over time.

As part of attempts to gauge how LAD has changed in recent years, Singapore's experience and approach should be seriously considered comparatively in the context of the "new law and development."

\section{REFERENCES}

ASEAN (2015) “ASEAN Community Vision 2025," http://www.asean.org/storage/images/2015/ November/aec-page/ASEAN-Community-Vision-2025.pdf (accessed 7 March 2018).

ASEAN (2018) "ASEAN Member States," http://asean.org/asean/asean-member-states/ (accessed 7

March 2018).

83. Shanmugam, supra note 5. 
Asian Business Law Institute (2016) "Singapore Hosts Inaugural International Conference on Convergence of Asian Business Laws," http://abli.asia/NEWS-EVENTS/Whats-New/ID/12 (accessed 7 March 2018).

Attorney-General's Chambers (2012) “Annual Report 2010-2011,” https://www.agc.gov.sg/docs/ default-source/Publications/annual-report-2010-2011.pdf?sfvrsn=4 (accessed 7 March 2018).

Attorney-General's Chambers (2013) “Annual Report 2012," https://www.agc.gov.sg/docs/defaultsource/Publications/annual-report-2012.pdf?sfvrsn=2 (accessed 7 March 2018).

Attorney-General's Chambers (2015) “Annual Report 2013-2014," https://www.agc.gov.sg/docs/ default-source/Publications/annual-report-2013-2014.pdf?sfvrsn=4 (accessed 7 March 2018).

Attorney-General's Chambers (2018) “About Us," https://www.agc.gov.sg/about-us/overview (accessed 7 March 2018).

Carter, Connie (2002) Eyes on the Prize: Law and Economic Development in Singapore, The Hague: Kluwer.

Centre for International Law-National University of Singapore (2018a) "ASEAN," https://cil.nus. edu.sg/research-projects/asean-law-policy/asean/ (accessed 7 March 2018).

Centre for International Law-National University of Singapore (2018b) "ASEAN Integration through Law," https://cil.nus.edu.sg/research/asean-law-policy/topics/asean-integration-throughlaw/ (accessed 7 March 2018).

Centre for International Law-National University of Singapore (2018c) "Introduction," https://cil.nus. edu.sg/about-us/mission-and-vision/ http://law.nus.edu.sg/cals/ (accessed 7 March 2018).

Chan, Wing Cheong, M. MacBride, M. Hor, N. A. Morgan, S. M. H. Yeo, \& W. C. Chan (2017) Criminal Law in Myanmar, Singapore: LexisNexis.

Channel NewsAsia (2016) "World Bank No Longer Distinguishing between 'Developed' and 'Developing' Countries," https://www.channelnewsasia.com/news/world/world-bank-no-longerdistinguishing-between-developed-and-dev-8002870 (accessed 7 March 2018).

Corrupt Practices Investigation Bureau (2016) "Roles and Functions," https://www.cpib.gov.sg/aboutcpib/roles-and-functions (accessed 7 March 2018).

Deinla, Imelda (2017) Development of the Rule of Law in ASEAN: State and Regional Integration, Cambridge: Cambridge University Press.

deLisle, Jacques (1999) "Lex Americana? United States Legal Assistance, American Legal Models, and Legal Change in the Post-Communist World and Beyond." 20 University of Pennsylvania Journal of International Law 179-308.

Harding, Andrew (2014) "Law and Development in its Burmese Moment: Legal Reform in an Emerging Democracy," in T. Lindsey \& M. Crouch, eds., Law, Society and Transition in Myanmar, Oxford: Hart Publishing, 377-99.

Harding, Andrew, \& Thu Hien Bui (2017) "Law and Regional Development in ASEAN: A Singapore Perspective," NUS CALS Working Paper 17/02, https://law.nus.edu.sg/wps/pdfs/ 012_2017_Andrew\%20Harding.pdf (accessed 7 March 2018).

Harding, Andrew \& Connie Carter (2003) "Cutting through the Complexity: The Singapore Model of Law and Development," in A. Perry-Kessaris \& J. Hatchard, eds., Law and Development: Facing Complexity in the $21^{\text {st }}$ Century, London: Cavendish, 191-206.

Harding, Andrew, \& Maartje de Visser (2017) "Teaching Comparative Law in Singapore”, in J. Hu, A. Harding, \& M. de Visser, eds., Legal Education in Asia: From Imitation to Innovation, Leiden: Brill, 102-24.

Harding, Andrew, \& Khin Khin Oo (2017) Constitutionalism and Legal Change in Myanmar, Oxford: Hart Publishing

Hin, Koh Teck (2013) "Corruption Control in Singapore," https://www.unafei.or.jp/publications/pdf/ RS_No83/No83_17VE_Koh1.pdf (accessed 7 March 2018).

Human Rights Resource Centre (2015) "HRRC, SMU, CALS, and ASEAN CSR Network Hold Side Event at the ASEAN Next-Gen CSR Forum in Bali," http://hrrca.org/hrrc-smu-cals-and-asean-csrnetwork-hold-side-event-at-the-asean-next-gen-csr-forum-in-bali/ (accessed 7 March 2018).

Humphreys, Stephen (2010) Theatre of the Rule of Law: Transnational Legal Intervention in Theory and Practice, Cambridge: Cambridge University Press. 
Institute of Southeast Asian Studies (2018) "Mission," https://www.iseas.edu.sg/about-us/mission (accessed 7 March 2018).

International Bar Association (2015) "Singapore: Fifty Years of the Rule of Law," http://www.ibanet. org/Article/Detail.aspx?ArticleUid=09014a7c-65ce-40ab-bdab-a7c443682083 (accessed 7 March 2018). 9

International Bridges to Justice (2018) "Singapore," http://www.ibj.org/where-we-work/singapore/ (accessed 7 March 2018).

Law School—National University of Singapore (2018a) "About CALS," http://law.nus.edu.sg/cals/ (accessed 7 March 2018).

Law School—National University of Singapore (2018b) “About NUS Law,” https://law.nus.edu.sg/ about_us/index.html (accessed 7 March 2018).

Law School—Singapore Management University (2018) “About SMU SOL," https://law.smu.edu.sg/ aboutsmusol (accessed 7 March 2018).

Law Society of Singapore (2018) "Organisation Structure," https://www.lawsociety.org.sg/About-Us/ Organisation-Structure (accessed 7 March 2018).

Lee, Jack Tsen-Ta (2012) "Shall the Twain Never Meet? Competing Narratives and Discourses of the Rule of Law in Singapore." Singapore Journal of Legal Studies 298-330.

Lee, Kuan Yew (1998a) From Third World to First: The Singapore Story 1965-2000, New York: Harper Collins.

Lee, Kuan Yew (1998b) "The Secret of Good Government," in H. F. Kwang, W. Fernandez \& S. Tan, eds., Lee Kuan Yew: The Man and His Ideas, Singapore: Times Editions.

Lee, Kuan Yew (2012) The Singapore Story: Memoirs of Lee Kuan Yew, Singapore: Marshall Cavendish.

Lee Kuan Yew School of Public Policy—National University of Singapore (2018) “Dean's Welcome," https://lkyspp.nus.edu.sg/explore-lkyspp/deans-welcome (accessed 7 March 2018).

McAuslan, Patrick (2004) "In the Beginning Was the Law ... an Intellectual Odyssey," The Practice of Law and Development: Socio-Legal Approaches, No.2 (Cornell University), https://scholarship. law.cornell.edu/ealccs_pld/2 (accessed 7 March 2018).

Menon, Sundaresh (2013) "Transnational Commercial Law: Realities, Challenges and a Call for Meaningful Convergence." Singapore Journal of Legal Studies 231-52.

Ministry of Foreign Affairs Singapore (2018a) "About MFA," https://www.mfa.gov.sg/content/mfa/ index.html (accessed 7 March 2018).

Ministry of Foreign Affairs Singapore (2018b) "Singapore Technical Cooperation with LAO PDR," https://www.mfa.gov.sg/content/mfa/overseasmission/vientiane/singapore_technical_cooperation. html (accessed 7 March 2018).

Ministry of Foreign Affairs Singapore (2018c) "Technical Cooperation Program," https://www.mfa. gov.sg/content/mfa/overseasmission/manila/singapore_cooperationprogramme.html (accessed 7 March 2018).

Ministry of Law Singapore (2008) "Singapore and Vietnam Sign Agreement on Legal and Judicial Cooperation," https://www.mlaw.gov.sg/content/minlaw/en/news/press-releases/singapore-andvietnam-sign-agreement-on-legal-and-judicial-cooperation.html (accessed 7 March 2018).

Ministry of Law Singapore (2014a) "Senior Minister of State for Law, Indranee Rajah, Concludes Working Visit to Myanmar," https://www.mlaw.gov.sg/content/minlaw/en/news/press-releases/ SMS-working-visit-to-myanmar.html (accessed 7 March 2018).

Ministry of Law Singapore (2014b) "Visit of Senior Minister of State for Education and Law Indranee Rajah to Myanmar, 18 to 20 February 2014," https://www.mlaw.gov.sg/content/minlaw/en/news/ press-releases/visit-of-SMS-to-myanmar-2014.html (accessed 7 March 2018).

Ministry of Law Singapore (2017) "Raising the Bar, Accounting for the Future," https://www.mlaw. gov.sg/content/dam/minlaw/corp/News/Note\%20on\%20CFE\%20Legal\%20and\%20Accounting\% 20Services.pdf (accessed 7 March 2018).

Ministry of Law Singapore (2018) "What We Do," https://www.mlaw.gov.sg/content/minlaw/en/ about-us/what-we-do.html (accessed 7 March 2018). 
National University of Singapore (2018) "NUS Graduate Scholarship for ASEAN Nationals," http:// www.nus.edu.sg/admissions/graduate-studies/scholarships-financial-aid-and-fees/scholarshipsawards/nus-gsa.html (accessed 7 March 2018).

Newton, Scott (2008) "Law and Development, Law and Economics and the Fate of Legal Technical Assistance," in J. Arnscheidt, B. van Rooij, \& J. M. Otto, eds., Lawmaking for Development: Explorations into the Theory and Practice of International Legislative Projects, Leiden: Leiden University Press, 23-52.

Prosperity.com (2017) "Legaltum Prosperity Index," http://www.prosperity.com/\#!/ranking (accessed 7 March 2018).

Quah, Jon (2017) “Singapore's Success in Combating Corruption: Lessons for Policy Makers.” 6 Asian Education and Development Studies 263-74.

Rajah \& Tann Asia (2018) "Changing the Game in Delivering Legal Services around South East Asia," https://www.rajahtannasia.com/singapore-law-firm-network (accessed 7 March 2018).

Shanmugam, Kasiviswanathan (2012) "The Rule of Law in Singapore." Singapore Journal of Legal Studies 357-65.

Singapore Academy of Law (2018) "Introduction," https://www.sal.org.sg/About-Us/Introduction (accessed 7 March 2018).

Singapore International Arbitration Centre (2018) “About Us,” http://siac.org.sg/2014-11-03-13-3343/about-us (accessed 7 March 2018).

Singapore International Commercial Court (2018) "Overview of the SICC," https://www.sicc.gov.sg/ about-the-sicc/overview-of-the-sicc/ (accessed 7 March 2018).

Singapore International Mediation Centre (2018) "Mediation in Singapore," http://simc.com.sg/mediationin-singapore/ (accessed 7 March 2018).

Singapore Management University (2018) “ASEAN Undergraduate Scholarship," https://admissions. smu.edu.sg/scholarships/asean-undergraduate-scholarship (accessed 7 March 2018).

Singapore Mediation Centre (2018) "About Us," http://mediation.com.sg/about-us/ (accessed 7 March 2018).

Singapore Parliament (1991) Shared Values, Singapore: Singapore National Printers.

State Courts-Singapore (2018) "Court Governance and Administration," https://www.statecourts. gov.sg/AboutStateCourts/Pages/CourtGovernanceandAdministration.aspx (accessed 7 March 2018).

Straits Times (2014) "Singapore and Myanmar Boost Legal Cooperation through New Agreements," Straits Times, 11 October.

Supreme Court of Singapore (2016) "International Training Programmes 2016," http://www.supremecourt. gov.sg/sjc/judicial-education/international/2016\# (accessed 7 March 2018).

Supreme Court of Singapore (2018a) "International Alumni," http://www.supremecourt.gov.sg/sjc/ collaboration/international-alumni (accessed 7 March 2018).

Supreme Court of Singapore (2018b) "Structure of the Courts," https://www.supremecourt.gov.sg/ about-us/the-supreme-court/structure-of-the-courts (accessed 7 March 2018).

Supreme Court of the Union (The Republic of the Union of Myanmar), The (2015) "Conducting Mediation Skills Workshop for Judges," http://www.unionsupremecourt.gov.mm/?q=news/121 (accessed 7 March 2018).

Tan, Kevin Y. L. (2002) "The Role of Public Law in a Developing Asia." Singapore Journal of Legal Studies 265-86.

Taylor, Veronica (2010a) “Displacing 'Development': The New Agenda for Rule of Law Assistance.” 104 Northwestern University Law Review 260-1.

Taylor, Veronica (2010b) "Japan's Legal Technical Assistance: A Different Modernization Narrative?," in D. K. Linnan, ed., Legitimacy, Legal Development and Change: Law and Modernization Reconsidered, Farnham: Ashgate, 235-49.

Taylor, Veronica (2010c) "Rule-of-Law Assistance Discourse and Practice: Japanese Inflections," in J. Faundez \& A. Perry-Kessaris, eds., Law in the Pursuit of Development: Principles into Practice?, Abingdon \& New York: Routledge, 161-79. 
Temasek Foundation (2018) "Temasek Family of Foundations," http://www.temasekfoundation.org. sg/\#nav-philosophy (accessed 7 March 2018).

Thio, Li-Ann (2002) "Lex Rex or Rex Lex? Competing Conceptions of the Rule of Law in Singapore." 20 Pacific Basin Law Journal 1-76.

Thio, Li-Ann (2012) "Between Apology and Apogee, Autochthony: The 'Rule of Law' Beyond the Rules of Law in Singapore." Singapore Journal of Legal Studies 269-97.

Trading Economics (2018) "Corruption Rank," http://www.tradingeconomics.com/singapore/corruptionrank (accessed 7 March 2018).

Trubek, David M., \& Alvaro Santos (2006) The New Law and Economic Development: A Critical Appraisal, New York: Cambridge University Press.

Tu, Weiming (1984) Confucian Ethics Today: The Singapore Challenge, Singapore: Federal Publications.

UN Sustainable Development Goals (2015) "Sustainable Development Goal 16," https://sustainablede velopment.un.org/sdg16 (accessed 7 March 2018).

Vietnam News Agency (2015) "VN Seeks Singapore's Help on Anti-Corruption," http://vietnamnews. vn/society/273393/vn-seeks-singapores-help-on-anti-corruption.html\#XRSy0ExREOefwQEv.99 (accessed 7 March 2018).

Vietnam News Agency (2016) “ASEAN Chief Justices Gather in HCM City," http://vietnam.vnanet. vn/english/asean-chief-justices-gather-in-hcm-city/225920.html (accessed 7 March 2018).

Wigdor, Mitchell (2013) No Miracle: What Asia Can Teach all Countries about Growth, London: Routledge.

Wong, Yvonne (2016) Money Matters in Myanmar: Banking and Finance Law and Practice, Singapore: LexisNexis.

Woon, Walter (2015) The ASEAN Charter: A Commentary, Singapore: NUS Press.

World Bank (1993) "The East Asian Miracle: Main Report," http://documents.worldbank.org/curated/ en/975081468244550798/Main-report (accessed 12 February 2018).

Zan, Myint (2017) "Rule of Law Concepts in Burma's Constitutions and Actual Practice: No Ground for Optimism," in A. Harding \& K. K. Oo, eds., Constitutionalism and Legal Change in Myanmar, Oxford: Hart Publishing, 25-46. 